\title{
Missão Cumprida
}

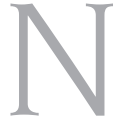

esta edição, a Revista Brasileira de Reumatologia (RBR) conta com a preciosa colaboração de competentes profissionais em quatro artigos originais, dois artigos de revisão e três relatos de caso, além das tradicionais seções de imagem, atualização e pausa entre consultas. Mais uma vez, a RBR traz trabalhos de excelente qualidade e grande utilidade para nossa prática clínica diária.

Diferentemente das edições anteriores, queremos aproveitar esta oportunidade para encerrar um ciclo importante de nossa vida profissional. Passados 24 meses à frente da RBR, e após 12 edições publicadas, abrimos espaço para a renovação deste diferenciado meio de comunicação científica. Oferecemos nossas boas-vindas aos dois novos editores e amigos, Dr. Ricardo Xavier, do Rio Grande do Sul, e Dr. Francisco Airton, do Ceará, que, desta forma, unirão experiências de duas extremidades deste nosso imenso país.

Agradecemos a valiosa colaboração do Conselho Editorial da RBR, que tanto nos auxiliou na seleção dos artigos recebidos, assim como pelas precisas sugestões para aprimoramento do conteúdo científico publicado durante toda nossa gestão. Agradecemos em especial ao Dr. Fernando Cavalcanti. Durante a sua gestão, ele dedicou parte do seu tempo à viabilização financeira da RBR e às questões de expansão internacional de nossa publicação, além de efetivar o acesso on-line, após diversas reuniões com o Scielo. Desde então, nossa revista vem recebendo acessos expressivos pela internet.

Foi um trabalho gratificante, do qual sentiremos falta. Temos a certeza de que nossa revista encontrase, atualmente, em fase de grande expansão e com elevado teor científico. Isso se deve, principalmente, ao trabalho em equipe e aos nossos colegas, que procuram compartilhar os resultados de seus trabalhos, enviandoos para serem divulgados nesta que é a maior e melhor revista de reumatologia da América Latina.

Lais V. Lage e Roger A. Levy Editores Científicos da RBR (2004-2006) 